\title{
Ultrastructural CHANGES IN PARASITES INDUCED BY NANOPARTICLE-BOUND PENTAMIDINE IN A LEISHMANIA MAJOR/MOUSE MODEL
}

\author{
FUSAI T.*, BOULARD Y.**, DURAND R.***, PAUL M.****, BORIES C.*****, \\ RIVOLLET D.***, ASTIER A.****, HOUIN R.*** \& DENIAU M.***
}

Summary :

Drug targeting enhances drug efficacy. This principle was tested in the treatment of an experimental visceral leishmaniasis. Using transmission electron microscopy (TEM) we localized pentamidineloaded polymethacrylate nanoparticles in the liver of mice infected with Leishmania major and compared the ultrastructural changes in the parasites of these mice when they were treated with bound versus free pentamidine. Between days 13 and 17 after infection, loaded nanoparticles treated group were injected i. v. with 3 doses of $0.17 \mathrm{mg} / \mathrm{kg}$ bound pentamidine loaded on $2 \times 10^{11}$ nanospheres; control groups received

$2 \times 10^{11}$ unloaded nanospheres. Drug reference control groups received five doses of $200 \mathrm{mg} / \mathrm{kg}$ pentavalent antimony (Glucantime®) or three doses of free pentamidine $10.17 \mathrm{mg} / \mathrm{kg}$ or $2.28 \mathrm{mg} / \mathrm{kg}$. Mice treated with bound pentamidine displayed a $77 \%$ reduction in their parasite burden versus the untreated controls. Nanoparticles were located by TEM inside parasitized Küpffer cells, in the phagolysosomes without entering the Leishmania. The low dose of $0.17 \mathrm{mg} / \mathrm{kg}$ bound pentamidine damaged the Leishmania to the same extent as $2.28 \mathrm{mg} / \mathrm{kg}$ of free pentamidine (the usual dose in human chemotherapy). In the parasites inside the Küpffer cells, TEM showed a swollen mitochondrion with loss of cristae, destruction or fragmentation of the kinetoplast, loss of ribosomes and destruction of parasite structures except for the subpellicular microtubules. This study therefore shows that a dose of bound pentamidine 13 times smaller than the usual dose of free pentamidine has a similar effect on the parasite.

KEY WORDS : murine visceral leishmaniasis, pentamidine, drug carrier, electron microscopy.

\section{INTRODUCTION}

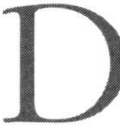

rug distribution can be controlled in different ways, one of which is the drug carrier system. This system can improve drug efficacy. This

\footnotetext{
* Médecin des Armées, IMTSSA, 13998 Marseille.

${ }^{* *}$ Laboratoire de Biologie Parasitaire, Protistologie et Helminthologie. Muséum National d'Histoire Naturelle, 61, rue Buffon, 75231 Paris Cedex 05

*** Laboratoire de Parasitologie, Faculté de Médecine, 94010 Créteil. **** Service de Pharmacologie-Toxicologie, Hôpital Henri-Mondor, 94010 Créteil.

***** Laboratoire de Parasitologie, Faculté de Pharmacie, 92000 Chatenay-Malabry

Correspondence: Michèle Deniau.

Tel: 0149813631 - Fax: 0149813601.
}

Résumé : MODIFICATIONS ULTRASTRUCTURALES DES LEISHMANIES INDUITES PAR PENTAMIDINE VECTORISÉE SUR UN MODÈLE DE LEISHMANIOSE VISCÉRALE MURINE

La vectorisation facilite l'accès de certaines drogues aux parasites intra-cellulaires. Ce concept a été appliqué à un modèle de leishmaniose expérimentale murine au cours duquel des souris $B A L B / c$ infectées par une souche de Leishmania major ont été traitées par pentamidine vectorisée sur nanoparticules de polyméthacrylate. Du $13^{\text {ème }}$ au 17 ème jours les souris ont reçu par voie i. v. 0,17 mg/kg de pentamidine chargée sur

$2 \times 10^{11}$ nanoparticules. Les souris des groupes témoins ont reçu soit $2 \times 10^{11}$ nanoparticules non chargées, soit $2.28 \mathrm{mg} / \mathrm{kg}$ ou $0,17 \mathrm{mg} / \mathrm{kg}$ de pentamidine libre, soit un traitement de référence $1200 \mathrm{mg} / \mathrm{kg}$ de glucantime®). Les souris traitées par pentamidine vectorisée ont présenté une réduction de leur charge parasitaire de $77 \%$ par rapport au groupe témoin non traité. Les nanoparticules ont été mises en évidence par microscopie électronique dans les cellules de Küpffer. Certaines étaient à l'intérieur des vacuoles parasitophores au contact des leishmanies mais aucune n'a été vue dans les parasites. Les altérations des leishmanies traitées par $0,17 \mathrm{mg} / \mathrm{kg}$ de pentamidine vectorisée étaient identiques à celles des leishmanies traitées par $2,28 \mathrm{mg} / \mathrm{kg}$ de pentamidine libre (dose habituelle chez I'homme). Les parasites présentaient une mitochondrie dilatée ayant perdu ses crêtes, un kinétoplaste partiellement détruit, une diminution des ribosomes, seuls les microtubules restaient intacts. Au cours de cette étude la pentamidine vectorisée a produit les mêmes modifications ultrastructurales qu'une dose de pentamidine libre 13 fois supérieure.

MOTS CLÉS : leishmaniose viscérale murine, pentamidine, vectorisation, microscopie électronique.

principle was first applied successfully with antineoplastic drugs (Astier et al., 1988, Chiannikulchaï et al., 1989). To date, drug carriers have proved to be of potential interest in the treatment of intracellular macrophage infections (Fattal et al., 1989), including visceral leishmaniases.

To improve the condition of patients with a chronic or relapsing course following drug therapy, more efficient and easily administrable drugs are required (Croft et al., 1991). Treatment with pentamidine is not fully effective and has toxic side effects, nevertheless it is used against species such as Leishmania braziliensis (Soto et al., 1994) or after failure of treatment with other drugs (Croft \& Davidson, 1993). Pentamidine bound to a colloidal drug carrier might enhance its efficacy and reduce its toxicity. This procedure was tested 
in our laboratory in an in vitro model, using the monohistiocytic U 937 cell line and L. major amastigotes. In this model, pentamidine loaded polymethacrylate nanoparticles were twenty times more active than free pentamidine (Deniau et al., 1993). In vivo, with a leishmaniasis/BALB/c mouse model, these results were confirmed by light microscopy (Fusai et al., 1994).

The aims of the present study were to localize the nanoparticles in the liver by transmission electron microscopy (TEM), to confirm that they are harmless to the host cells, to examine the parasite changes in the Küpffer cells of mice treated with bound pentamidine and to compare the changes in groups which were untreated or treated with free pentamidine.

\section{MATERIALS AND METHODS}

lowly biodegradable polymethacrylic nanoparticles, with diameter of up to about $300 \mathrm{~nm}$ were used as drug carriers. The number of nanoparticles per $\mathrm{ml}$ was estimated in function of polymeric density and of the volume of one nanoparticle. They were loaded with pentamidine by ionic binding on free carboxylic groups, as previously described (Paul et al., 1997).

Pentamidine bound nanoparticles were assayed on the murine model of visceral leishmaniasis as previously described (Fusai et al., 1993). Briefly, promastigotes of $L$. major MON 74, cryopreserved or maintained in golden hamsters were cultivated for this study on RPMI medium. On day $0,4 \times 10^{7}$ infective promastigotes were injected via the tail vein. The mice were then randomly divided into six groups of ten animals (Table I). Group 1 received isotonic sodium chloride. Group 2 received Glucantime ${ }^{\circledR}$ as drug reference treatment. Group 3 received $0.17 \mathrm{mg} / \mathrm{kg}$ bound pentamidine loaded on $2 \times 10^{11}$ nanoparticles (i. e. $13.6 \mu \mathrm{g}$ of pentamidine per $\mathrm{mg}$ of polymere). Group 4 received $2 \times 10^{11}$ unloaded nanoparticles. Group 5 and 6 received free pentamidine. Twelve days after infection, severe visceralization was obtained, with an average liver parasite burden of $12.9 \times 10^{8}$. Treatments were given from day 13 to 17 and, on day 21 the ani-

- Group 1: Untreated control mice

- Group 2: Drug reference control mice (i. e. 200 mg/kg Glucantime ${ }^{\circledR} \times 5$, i. p.)

- Group 3: Loaded nanoparticle-treated mice $(0.17 \mathrm{mg} / \mathrm{kg}$ of pentamidine base $\times 3$, i. v.)

- Group 4: Unloaded nanoparticle-treated mice $(0.1 \mathrm{ml} \times 3$, i. v. $)$

- Group 5: Free pentamidine-treated mice $(2.28 \mathrm{mg} / \mathrm{kg}$ of pentamidine base $\times 3$, i. v.)

- Group 6: Free pentamidine-treated mice $(0.17 \mathrm{mg} / \mathrm{kg}$ of pentamidine base $\times 3$, i. v.)

Table 1. - The different groups of treated or untreated mice. mals were killed and autopsied. Drug efficacy was determined by evaluating the liver parasite burden according to Stauber (Stauber et al., 1958).

Histological sections were prepared for electron microscopy as follows: pieces of liver, roughly $1 \mathrm{~mm}^{3}$, were fixed for one hour at $4{ }^{\circ} \mathrm{C}$ in $2 \%$ glutaraldehyde in $0.1 \mathrm{M}$ cacodylate buffer ( $\mathrm{pH} 7.4$ ), rinsed three times in this buffer at $4{ }^{\circ} \mathrm{C}$, and post-fixed in $2 \%$ osmium tetroxide in the same buffer. $0.5 \%$ potassium ferricyanide was added to both fixatives. The samples were rinsed three times in distilled water, kept in $0.5 \%$ uranyl acetate water solution (v/v) for 12 hours, at $4{ }^{\circ} \mathrm{C}$ and dehydrated in graded ethanol solution. The samples were then washed twice with propylene oxide and embedded in a 1:1 mixture of araldite with epon. Fifty nm sections were cut with a diamond knife and stained with uranyl acetate and lead citrate. The fine structure was examined with a Phillips EM 201 electron microscope, at the CIME (Centre Interuniversitaire Jussieu de Microscopie Électronique, quai Saint-Bernard, 75252 Paris Cedex 05).

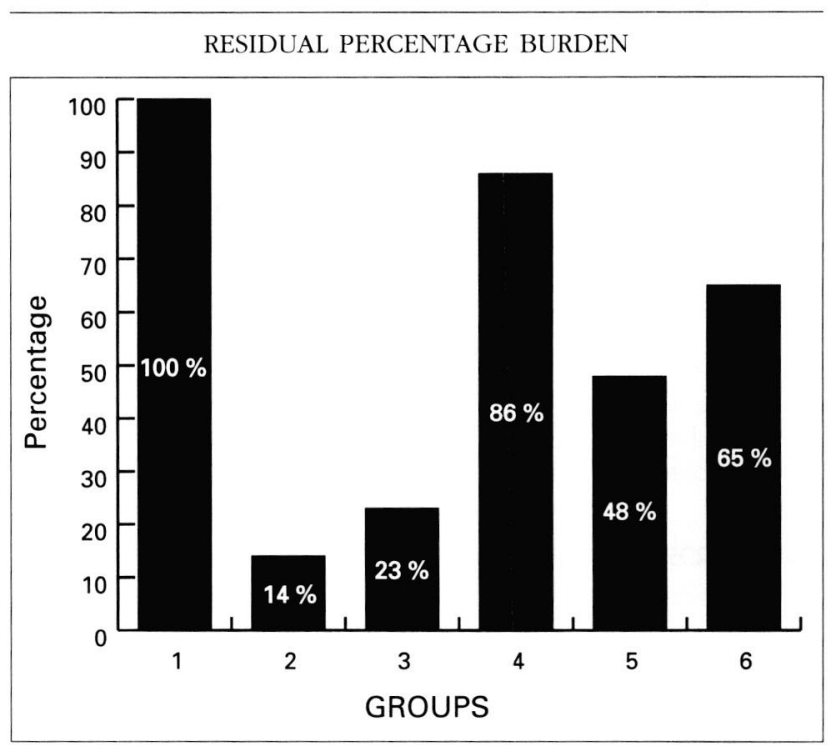

Group 1: Untreated control mice: the parasite burden, considered as $100 \%$, reached $12 \times 10^{8}$.

Group 2: Glucantime treated mice: the residual burden percentage dropped dramatically. The difference between Glucantime-treated and the bound pentamidine-treated mice was small.

Group 3: Bound pentamidine-treated mice: the residual parasite burden fell to $23 \%$.

Group 4: Unloaded nanoparticle treated mice: nanoparticles were ineffective in reducing the burden.

Group 5: With the usual dosage of $2.28 \mathrm{mg} / \mathrm{kg} \times 3$ free pentamidine, the burden of $48 \%$ was the average one expected.

Group 6: At the low dosage of $0.17 \mathrm{mg} / \mathrm{kg} \times 3$ free pentamidine did not reduce the burden effectively.

Fig. 1. - The residual Leishmania burden in different groups of treated mice compared to the untreated controls. 


\section{RESULTS}

Electron microscopy study revealed the following features:

\section{CONTROL GROUPS}

\section{- Untreated mice}

In the Küpffer cells of untreated mice (Fig. 2), amastigotes exhibited their well known characteristic structures: a condensed kinetoplast, a mitochondrion with a double wall membrane and clearly delineated cristae. The ribosomes, nucleus, microtubular and flagellar structures were intact. They had the morphology reported by different authors (Langreth et al., 1983, Molyneux \& Killick-Kendrick, 1987).

- Mice treated with free pentamidine

Free pentamidine did not alter the kinetoplast (Fig. 5) at the dose of $0.17 \mathrm{mg} / \mathrm{kg}$, i. e. the low dosage targeted in nanoparticles. However, at the usual dose of $2.28 \mathrm{mg} / \mathrm{kg}$, it caused the typical ultrastructural changes induced by pentamidine (Croft \& Brazil, 1982, Langreth et al., 1983), i. e. the mitochondrion was greatly distended, the matrix contained fragments of mitochondrial membrane and the kinetoplast was disrupted and electron-dense. The ribosomes were segregated and depleted (Fig. 6).

\section{MICE TREATED WITH BOUND-PENTAMIDINE}

Effective phagocytosis of nanoparticles was frequently observed, as demonstrated in Figure 3. On this section, up to 300 nanoparticles were concentrated around the nucleus of a Küpffer cell. Nanoparticles were also present in the lysosomial compartment of the parasitized cell but did not enter the parasite, although they were located close to it (Fig. 4).

Amastigotes displayed various ultrastructural changes, especially in the kinetoplast which was more dense and seemed free in a ruptured mitochondrion. Moreover, the mitochondrion lost its cristae and a part of its matrix. The ribosomes were segregated and depleted (Fig. 8 and 9). Other views showed profiles of swollen mitochondrion, but the microtubule of the flagellum and those of subpellicular structures were unchanged (Fig. 10). The proliferation of pseudomyelinic structures was frequently observed in these treated parasites (Fig. 11).

In the liver of mice treated with unloaded nanoparticles (Fig. 7) and loaded nanoparticles (Fig. 8), the host cells were not altered.

\section{DISCUSSION}

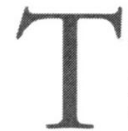

he ultrastructural changes induced by bound pentamidine that we observed in our study were similar to those described by Croft \& Brazil (1982) of L. amazonensis after treatment with free pentamidine, and by Hentzer \& Kobayasi (1977) in L. tropica. There is no study concerning the ultrastructural changes induced by pentamidine in L. major. Most publications concern other species (Croft \& Brazil, 1982; Langreth et al., 1983; Hentzer \& Kobayasi, 1977). In their review, Molyneux \& Killick-Kendrick (1987) hypothesized that Leishmania, whatever the species, could have a similar configuration and ultrastructural morphology.

In this study, the percent of decrease in the parasite burden in the mice treated with bound pentamidine was established by the Stauber method, which is limited to a light microscopy examination. The ultrastructural study confirmed that, in these mice, the alterations were indeed due to the action of pentamidine, in this group. It confirmed also the good penetration of the carrier into Küpffer cells, the amount of drug released in situ increasing with the number of phagocytized particles. Furthermore, morphologically the action of $0.17 \mathrm{mg} / \mathrm{kg}$ bound pentamidine was similar to that of $2.28 \mathrm{mg} / \mathrm{kg}$ free pentamidine. In the present experiment, the mice treated with bound pentamidine exhibited more numerous pseudo-myelinic bodies than did control mice. This probably reflects alterations in the phospholipidic system which appear to have been unnoticed by other authors. Hentzer \& Kobayasi (1977) observed multivesiculate bodies that we did not see. The mode of action of pentamidine is not quite clear and the images we obtained did not allow us to propose other hypothesis than those already suggested by different authors (Calonge et al., 1996, Kandpal et al., 1996). However, there is a reason to believe that the similarity of the ultrastructural changes in the group of mice treated with free and the group treated with bound pentamidine is due to a similar mode of action. The close contact between parasitophorous vacuole (PV) and phagolysosomes containing nanoparticles may be of crucial importance. Most of our micrographs show nanoparticles inside lysosomes, sometimes, in the PV, but we also observed free nanoparticles in the cell cytoplasm (as observed in the Figure 7), this could represent the last step of intracellular trafficking. An hypothesis proposed about the turn over of lysosome could explain this aspect: after neutralization of lysosomial enzymes, the membrane of lysosome has been disrupted, then the nanoparticles are in close contact to the cytoplasm. Our images did not show fusion between secondary lysosomes and the PV membrane. 

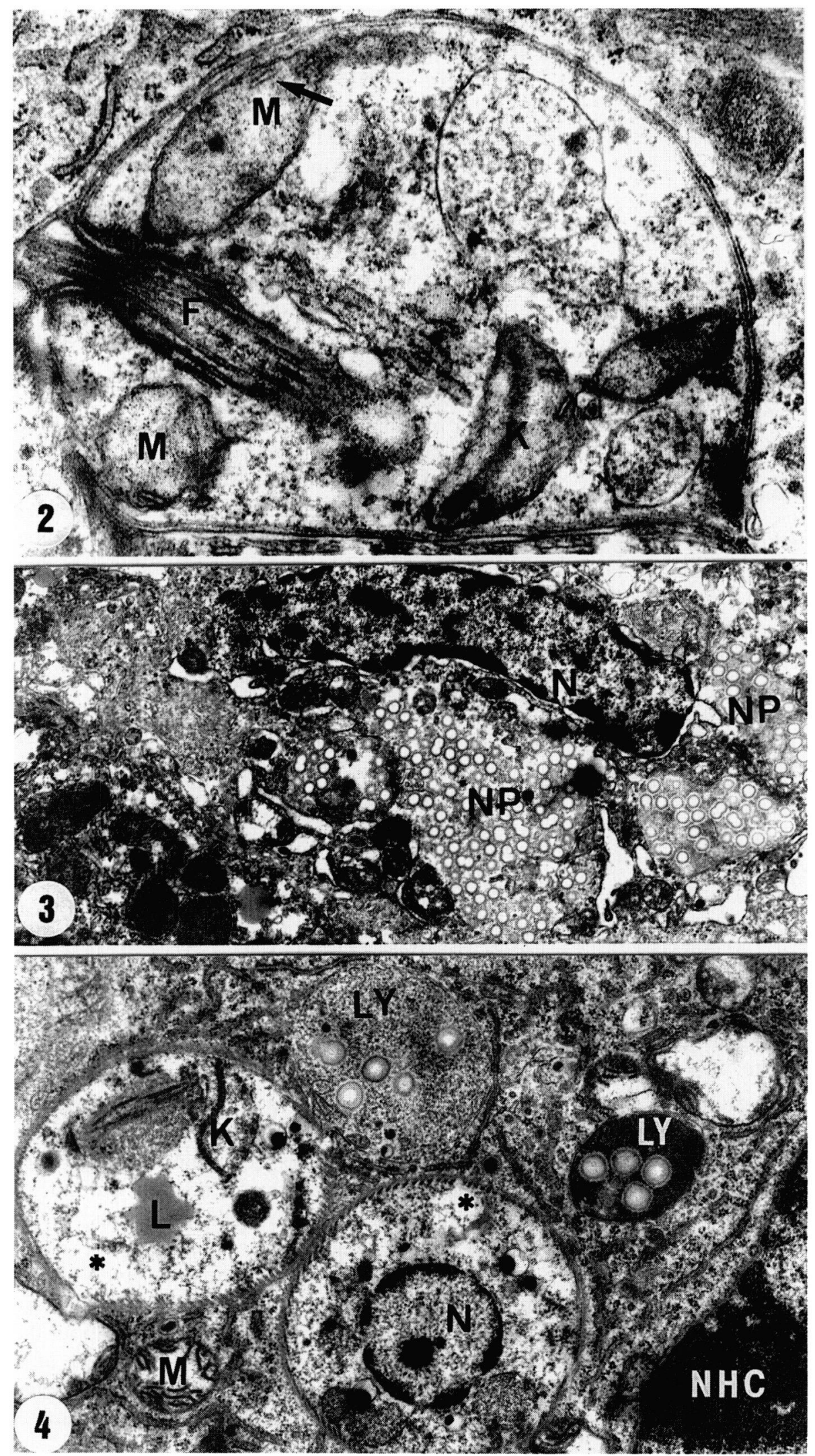

Untreated control groups

Fig. 2. - Leishmania in a Küpffer cell of an untreated mouse: the cell displays the normal ultrastructural features of a leishmania amastigote control, a mitochondrion (M) within a double membrane, a normal dense matrix containing cristae (arrow) and a prominent kinetoplast $(k)$. The flagellar pocket (F) is apparent. Parasitophorous vacuole membrane is close to the parasite $(\times 40,000)$.
Localization of nanoparticles (figures 3 and 4)

Fig. 3. - Küpffer cell of a mouse treated with bound pentamidine: The abundance of nanoparticles phagocytized by this Küpffer cell must be noted: nanoparticles (NP) are clustered in large vacuoles identified by their clearer aspect than the surrounding cytoplasme $(\mathrm{N}$ : nucleus of the Küpffer cells) $(\times 7,000)$.

Fig. 4. - Leishmania in a Küpffer cell of a mouse treated with bound pentamidine. The nanoparticles are localized in secondary lysosomes (LY) and seem to remain outside the parasites $\left(^{*}\right)$. One parasite shows alteration of the kinetoplast $(\mathrm{K})$ and of the lipid droplets (L) (NHC: nucleus of the host cell $)(\times 14,000)$ 

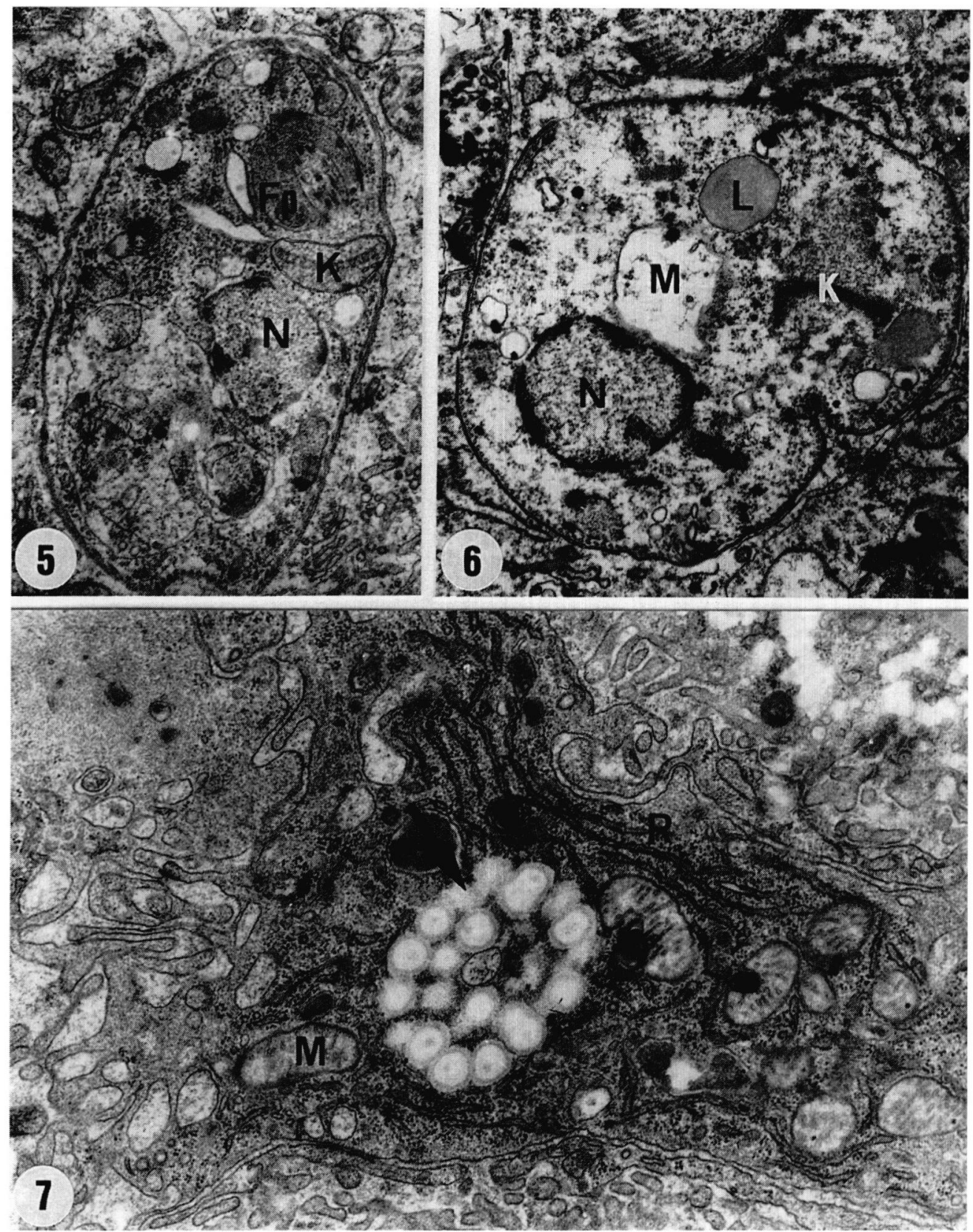

Figs. 5 to 7. - Controls of free pentamidine and unloaded nanoparticles treated groups: Fig. 5. - Leishmania in a Küpffer cell of a mouse treated with $0.17 \mathrm{mg} / \mathrm{kg} \times 3$ of free pentamidine. At this low dosage, similar to its concentration in nanoparticles, injection of free pentamidine did not alter the structures (Fp: Flagellar pocket, K: kinetoplast, N: nucleus) (× 16,000). Fig. 6. - Leishmania in a Küpffer cell of a mouse treated with $2.28 \mathrm{mg} / \mathrm{kg} \times 3$ of free pentamidine, Leishmania structures show the same alterations as with bound pentamidine treatment $(0.17 \mathrm{mg} / \mathrm{kg})$ : the kinetoplast $(k)$ shows disruption of the mitochondrion membrane and is more electrondense; the mitochondrion (M) is empty because of the loss of the matrix; ribosomes are segregated and depleted $(\times 20,000)$. Fig. 7 . - Küpffer cell of a mouse treated with unloaded nanoparticles, the host cell, observed 3 days after the last injection, is not affected by the drug carrier (arrow) (M: mitochondrion, R: rough endoplasmic reticulum) The nanoparticles are clustered $(\times 20,000)$. 


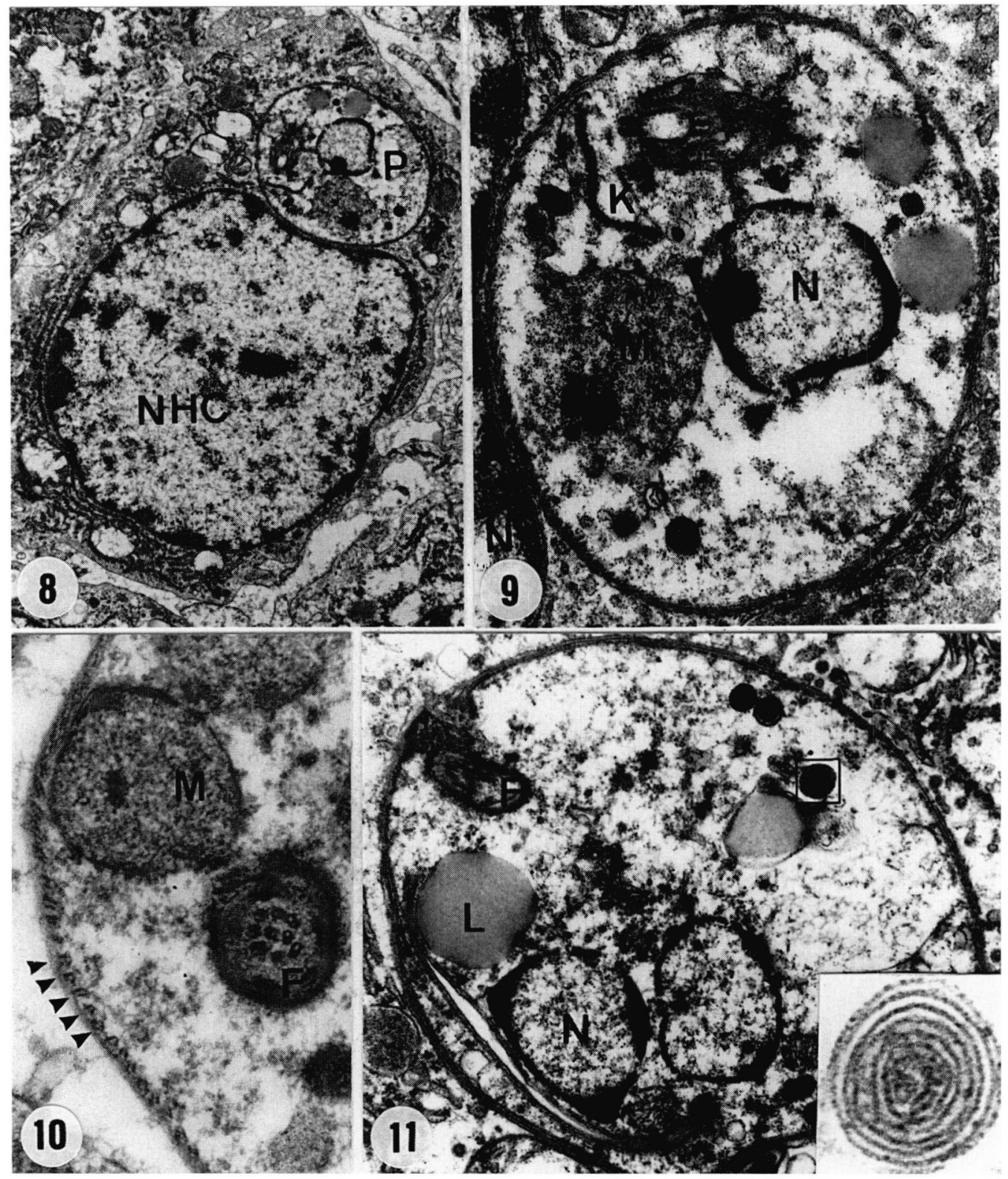

Bound-pentamidine treated group: Figs 8 to 11

Figs. 8 and 9. - Leishmania in a Küpffer cell of a mouse treated with bound pentamidine (concentration: 0,17 mg/kg). The host cell does not exhibit alteration (Fig. 8). The parasite (P) is shown with a higher magnification in Figure 9; the kinetoplast and mitochondrion (M) exhibit major changes: the kinetoplast $(\mathrm{K})$ is very electrondense and its membrane is disrupted, a part of the matrix is lost. In a profile of the mitochondrion, the membrane is also disrupted and if small cristae are still visible, the matrix seems being dispersed. Ribosomes are segregated and depleted. Nucleoplasma of the nucleus is clear $(\times 6,000$, and $\times 19,500)$. Fig. 10. - Leishmania in a Küpffer cell of a mouse treated with bound pentamidine, a swollen mitochondrion $(M)$ and segregated ribosomes contrast with the intact appearance of flagellar structures (F) and subpellicular microtubules (arrow-head) ( $\times$ 45,000). Fig. 11. - Leishmania in a Küpffer cell of a mouse treated with bound pentamidine, besides the usual changes due to pentamidine, more numerous pseudomyelinic multilamellar structures ( $\square$ ) than in controls can be observed $(\times 22,000)$; insert: a higher magnification of one of these structures $(\times 90,000)$. 
As far as we know, the type of carrier used here is the first to be loaded with pentamidine. Methacrylate polymer nanoparticles, which allow the ionic binding of drugs, have the advantage of releasing drugs at a low $\mathrm{pH}$, as encountered in the lysosomes. The release of the drug in situ close to the target, may reduce drug toxicity to the host. The lack of immediate side effects in the mice treated with bound pentamidine was evident. Pentamidine tolerance and toxicity could be improved by the use of drug carriers. Evaluation of these nanoparticles showed that the carrier was not toxic either, in vitro, for rat liver cells or, in vivo, in rabbit (Rolland, 1988). However a long time period of follow-up is required to assess the inocuity of these nanoparticles after chronic treatment in man.

These results, with bound pentamidine, show that drug carriers are of interest for the treatment of leishmaniasis. Other studies with a panel of drug carriers loaded with different drugs are now in progress.

\section{ACKNOWLEDGEMENTS}

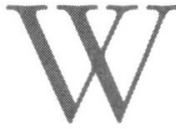
e wish to thank Dr. R. Killick-Kendrick for his critical reading of manuscript and Mrs Tchéprakoff for assistance in preparing the illustrations.

This investigation received financial support from the UNDP/WORLD BANK/WHO special Program for Research and Training in Tropical Diseases.

\section{REFERENCES}

Astier A., Doat B., Ferrer J.M., Benoit G., Fleury J., RolLAND A. \& Leverge R. Enhancement of Adriamycin antitumor activity by its binding with an intracellular sustainedrelease form, polymethacrylate nanospheres, in U 937 cells. Cancer Research, 1988, 48, 1835-1841.

Calonge M., Johnson R., Balana-Fouce R. \& Ordonez D. Effects of cationic diamidines on polyamine content and uptake on Leishmania infantum in in vitro cultures. Biochemical Pharmacology, 1996, 52, 835-841.

Chiannikulchai N., Priouch Z., Benoit S.P., Parodi A.L. \& CouVREUR P. DOXorubicin-loaded nanoparticles increased efficiency in murine hepatic metastases. Selection Cancer Therapy, 1989, 5, 96-106.

Croft S.L. \& BraziL R.P. Effect of pentamidine isethionate on the ultrastructure and morphology of Leishmania mexicana amazonensis in vitro. Annals of Tropical Medicine and Parasitology, 1982, 76, 37-43.

Croft S.L. \& DAvidson R.N. Recent advances in the treatment of visceral leishmaniasis. Transaction of the Royal Society of Tropical Medicine and Hygiene, 1993, 87, 130-131 \& 141 .
Croft S.L., Davidson R.N. \& Thorton E.A. Liposomal amphotericin B in the treatment of visceral leishmaniasis. Journal of Antimicrobial Chemotherapy, 1991, 28, 111-118.

Deniau M., Durand R., Bories C., Paul M., Astier A., Couvreur P. \& Houin R. Étude in vitro de médicaments leishmanicides vectorisés. Annales de Parasitologie Humaine et Comparée, 1993, 68, 34-37.

Fattal E., Youssef M., Couvreur P. \& Andremont A. Treatment of experimental salmonellosis in mice with ampicillin-bound nanoparticles. Antimicrobial Agents and Chemotherapy, 1989, 33, 1540-1543

Fusai T., Deniau M., Durand R., Bories C., Paul M., Rivollet D., Astier A. \& Houin R. Action of Pentamidinebound nanoparticles against Leishmania on an in vivo model. Parasite, 1994, 1, 319-324.

Fusai T., Deniau M., Gantier J.C., Bories C., Rivollet D. \& Houin R. Viscéralisation expérimentale de L. major sur la souris BALB/c. Bulletin de la Société Française de Parasitologie, 1993, 11, 17-22.

Hentzer B. \& Kobayasi T. The ultrastructural changes of Leishmania tropica after treatment with pentamidine. Annals of Tropical Medicine and Parasitology, 1977, 71, 157-166.

Kandpal M., Tekwani B.L., Chauhan P.M. \& Bhaduri A.P. Correlation between inhibition of growth and arginine transport of Leishmania donovani promastigotes in vitro by diamidines. Life Sciences, 1996, 59, 75-80.

Langreth S.G., Berman J.D., Riordan G.P. \& Lee L.S. Finestructural alterations in Leishmania tropica within human macrophages exposed to antileishmanial drugs in vitro. Journal of Protozoology, 1983, 30, 555-561.

Molyneux D.H. \& Killick-Kendrick R. Morphology, ultrastructure and life cycles. In: The Leishmaniases, Peters W. \& Killick-Kendrick R. 1st Edn, R. Academic Press Inc. Ed, London, 1987, 1, 121-176.

Paul M., Durand R., Boulard Y., Fusai T., Fernandez C., Rivollet D., Deniau M. \& Asdier A. Physiochemical characteristics of pentamidine-loaded polymethacrylate nanoparticles: implications in the intracellular drug release in Leishmania major infected mice. Journal of Drug Targeting, 1997 (in press).

Rolland A. Mise au point et applications des nanosphères à base de copolymères méthacryliques. Intérêts pour la vectorisation d'agents cytostatiques (antracyclines). Thèse de Doctorat de l'Université de Rennes I, mention Sciences biologiques et Santé, UER Médicales et Pharmaceutiques, 1987.

Soto J., Buffet P., Grogl M. \& Berman J. Successful treatment of Colombian cutaneous leishmaniasis with four injections of pentamidine. American Journal of Tropical Medicine and Hygiene, 1994, 50, 107-111.

Stauber L.A., Franchino E.M. \& Grun J. An eight-day method for screening compounds against Leishmania donovani in golden hamster. Journal of Protozoology, 1958, 5, 269273.

Reçu le 27 novembre 1996 Accepté le 20 mars 1997 